\title{
Erratum zu: Die Rolle des Partners und der Partnerin bei der Bewältigung arbeitsbedingter Belastungen
}

\section{Erratum zu:}

D. Niemann, Die Rolle des Partners und der Partnerin bei der Bewältigung arbeitsbedingter Belastungen, Gesundheitspsychologie, https://doi.org/10.1007/978-3-658-24906-9

Dieses Buch wurde zunächst mit falschen ISSN-Nummern publiziert.

Sie wurden im Impressum wie folgt korrigiert: ISSN 2662-3226, eISSN 2662-3234. 